\title{
An Analysis of Articles by College Librarians
}

\author{
Mickey Zemon and Alice Harrison Bahr
}

\begin{abstract}
College librarians recognize research and publication as important components of professional growth and communication. Yet, compared to their counterparts in universities, they author fewer articles in the professional literature. This paper examines articles published by college librarians in College \& Research Libraries and Journal of Academic Librarianship from 1986 to 1996 to provide a profile of college librarian authors and to identify factors that contributed to their success in publishing.
\end{abstract}

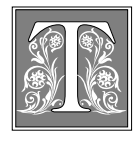

here has been considerable interest in promoting publication by college librarians during the past several years. In 1992, the College Library Section (CLS) of the ACRL established a committee to encourage college librarians to do research and to publish. The Research for College Librarianship Commitee drafted a research agenda that identified seven areas of college librarianship, with researchable questions in each area. It was posted on the Collib-l listserv in November 1993 and January 1994, formalized based on input from college librarians from across the country, approved by the CLS board, and subsequently published in the July 1995 issue of College $\mathcal{E}$ Research Library News.

The committee has sponsored panel sessions at the past two midwinter conferences, ${ }^{1}$ hosted roundtable discussions at national ACRL conferences, and published InPrint: Publishing Opportunities for College Librarians. ${ }^{2}$ A guide to journals that are potential publishers for college librarians, InPrint includes brief descriptions of editorial policies, topics covered, style and audience, and helpful breakdowns by acceptance rate.

Despite that interest and activity, however, publication in the professional literature is considered primarily an accomplishment of university, not college, librarians.

\section{Studies of Authorship}

Since 1985, several studies have profiled the characteristics of authors who published in library and information science journals. Although none focused specifically on college librarian authors, the research suggests that more authors from large university libraries and fewer from college libraries contribute to the literature.

\section{Size and Type of Library}

Examining twelve prominent library journals from 1973 to 1982, Sylvia C. Krausse and Janice F. Sieburth found that the most prolific authors worked in libraries with holdings of one or more million volumes. ${ }^{3}$ The data they gathered

Mickey Zemon is the Library Director at Emerson College; e-mail: ecl_maz@flo.org. Alice Harrison Bahr is the Director of the Library at Spring Hill College; e-mail: bahr@azalea.shc.edu. 
for Journal of Academic Librarianship (JAL) and College $\mathcal{E}$ Research Libraries (CERL) indicated that close to 60 percent of the articles published in these journals were by authors from large libraries.

\section{Beyond the need to publish for tenure and promotion, what moti- vates academic librarians to contrib- ute to the journal literature?}

John M. Budd and Charles A. Seavey investigated thirty-six library and information science journals from 1983 to 1987. ${ }^{4}$ Their findings were consistent with those of Krausse and Sieburth: Larger university libraries contributed the most productive authors. Peter Hernon, Allen Smith, and Mary Bailey Croxen examined the authorship of papers accepted or rejected by CERL from 1980 to $1991 .{ }^{5}$ Of the papers accepted, 6.2 percent of the authors were employed at baccalaureate institutions or community colleges, 16.1 percent at master's granting institutions, and 77.7 percent at doctoral granting institutions.

\section{Author's Occupation, Geographic Location, and Gender}

Lois Buttlar studied sixteen library periodicals between 1987 and 1989. ${ }^{6}$ She concluded that academic librarians, not library and information science faculty, accounted for the major share of publication activity, that the Northeast and Midwest contributed the largest share of authors, and that there were almost an equal number of articles written by men and women. Looking exclusively at articles published in CERL from 1989 to 1994, James L. Terry noted a significant increase in the number of articles published by female authors, as well as dramatic growth in collaborative authorship. ${ }^{7}$

\section{Reasons for Publishing}

The literature has addressed not only who published articles, but why they published them. Although no consensus ex- ists about the relationship between publication and tenure, W. Bede Mitchell and L. Stanislava Swieszkowski's study of authorship in research libraries concluded that tenure is the key impetus to publish. ${ }^{8}$ Barbara L. Floyd and John C. Phillips reported that publishing was a requirement for tenure for close to 80 percent of the surveyed authors. ${ }^{9}$ Others have looked at how evaluation criteria for academic librarians vary by type of academic institution. Using the 1987 Carnegie Classifications to distinguish among institutions, Betsy Park and Robert Riggs found that doctoral-granting and comprehensive universities were more likely to require evidence of publication than either research or liberal arts institutions. ${ }^{10}$ Liberal arts colleges were regarded as a distinctive group that was more oriented to teaching than to research, had smaller libraries with fewer staff, and rarely required librarians to publish.

Beyond the need to publish for tenure and promotion, what motivates academic librarians to contribute to the journal literature? Floyd and Phillips reported that most academic library authors were motivated internally by a desire to establish a professional reputation and by peer pressure from colleagues. ${ }^{11}$ Noting that many of the articles by academic librarians are descriptive or evaluative of on-the-job innovations, Paula D. Watson suggested that certain libraries provide a work environment that is conducive to research and publication. ${ }^{12}$ Following up on this concept, Kathleen Kenny, Linda D. Tietjen, and Rutherford W. Witthus described how one university library initiated a program of support, education, and information that encouraged more of its professional staff to publish. ${ }^{13}$

\section{Methods}

Using the definitions that follow, the authors entered data on articles published in CERL and JAL from 1986 to 1996 in a Microsoft Access database, created related files to collect in-depth information on 
college librarian authors, and surveyed those authors to develop a profile of college librarians who had published in these core journals.

\section{Definition of College Librarian}

Following the precedent established by earlier studies, this paper uses the Carnegie Classification to define type of institution. ${ }^{14}$ College librarians were defined as working in BAI, BAII, and MAII institutions at the time their article was published. Because the 1987 classifications were revamped in 1994, the following list includes 1987 equivalents for the categories BAI, BAII, and MAII:

- BAI: Primarily undergraduate, emphasis on baccalaureate programs, selective in admissions, and award 40 percent of baccalaureate degrees in the liberal arts (1987 equivalent-LAI);

- BAII: Primarily undergraduate, emphasis on baccalaureate programs, less selective in admissions, and award less than 40 percent of baccalaureate degrees in the liberal arts (1987 equivalent-LAII);

- MAII: Offer a full range of baccalaureate programs, committed to graduate education through the master's degree, and award twenty or more master's degrees annually in one or more disciplines (1987 equivalent-CompII) ${ }^{15}$

University librarians were defined as those working in institutions classified as research universities, doctoral universities, and master's universities and colleges (MAI), which award forty or more master's degrees annually in three or more disciplines. Institutions offering the associate of arts degree only, professional schools, and specialized institutions were excluded.

\section{Definition of Article}

The study includes only full-length, substantive articles by authors in academic in- stitutions in the United States. Editorials, contributions to symposia, book reviews, reprints, brief commentaries on articles or issues, and the "Research Notes" and "Selected Reference Books" sections in CERL were excluded.

Articles authored or coauthored by college librarians were counted as articles by college librarians, even if one of the authors was a university librarian. In the few instances in which two or more college authors collaborated on a single article, the article was counted once, but each author was given credit for a publication.

\section{Definition of Geographical Area or Region}

This article uses the designations of the 1978 ALA Committee on Accreditation for graduate library school programs to define geographic area or region.

\section{Determination of Subject Categories}

To capture a general sense of college librarian authors' major areas of interest, not the specific subject of each article, the authors established six broad subject areas: administration, collections, interlibrary loan (ILL), public services, technical services, and other. ILL was given its own category because some libraries include it under technical and others under public services.

\section{Rationale for Journal Selection}

Articles appearing in two core journals, $C \mathcal{E} R L$ and $J A L$, were selected because they are "by common consensus ... the major journals in academic librarianship,"16 because previous studies of authorship in $C \mathcal{E} R L$ offer useful, comparative data, and because these journals provide a solid platform for enlarging the current study. As refereed journals using blind review, these titles hold the most weight in terms of tenure and promotion decisions. Moreover, studies indicate that authors from academic libraries contribute heavily to both. ${ }^{17}$

\section{Description of Survey}

Because examining articles reveals little detail about authors or their motivation 
for publishing, the authors mailed a survey to the fifty-six college librarians with articles in CERL or JAL between 1986 and 1996. Ninety-three percent of those who received the survey responded. Modeled after Watson's survey of the publishing output of librarians at large university libraries, ${ }^{18}$ questions focused on the author's age, years in the profession, number of articles previously published, graduate degrees, institutional and external support, and motivation for writing.

\section{Findings}

Between 1986 and 1996, fifty-nine college librarians contributed fifty-four articles to either $C \mathcal{E} R L$ or JAL. Four articles were coauthored by college librarians. Of the fifty-nine college librarians, eight authored more than one article. One author wrote four articles, four wrote three, and three wrote two, which brings the total number of unique authors to forty-two.

\section{Publishing Output}

Of the 701 articles appearing in $C E R R L$ and JAL between 1986 and 1996, college librarians wrote fifty-four, or 8 percent. The percentage increases somewhat when the

College librarians were responsible for 11 percent ( 31 of the 276 articles by academic librarians) of the articles in $C \mathcal{E} R L$ and 10 percent (23 of the 210) of the articles in JAL.

output of college librarians is compared not to all articles in these journals but, rather, to articles by just academic librarians. Because university librarians authored 486, or 69 percent, of the 701 articles, college librarians were responsible for 10 percent of the total 540 articles by academic librarians.

This study confirms the assumption that publication in the professional literature is primarily the accomplishment of university, not college, librarians. The proportion of articles that college librar-

\begin{tabular}{|cc|}
\hline \multicolumn{2}{|c|}{$\begin{array}{c}\text { Table 1 } \\
\text { Articles Published per } \\
\text { Year, 1986-1996 }\end{array}$} \\
\hline \hline \multicolumn{2}{|c}{ Articles by } \\
Year & College Librarians \\
\hline 1996 & 4 \\
1995 & 4 \\
1994 & 9 \\
1993 & 6 \\
1992 & 8 \\
1991 & 5 \\
1990 & 4 \\
1989 & 4 \\
1988 & 3 \\
1987 & 1 \\
1986 & 6 \\
Total & 54 \\
\hline
\end{tabular}

ians publish in these journals is low compared to the proportion of college to university librarians in the profession and in ACRL. Of the 19,237 librarians and professional staff in BAI through Research Universities I institutions in 1994, 3,385, or 18 percent, were in BAI, BAII, or MAII schools. ${ }^{19}$ This is comparable to the 1997 ACRL membership statistics: 2,284, or 22 percent, of ACRL's 10,799 members belong to the CLS. ${ }^{20}$

There is no significant difference by journal. College librarians authored thirty-one of the 399 , or 8 percent, of the articles published in CERL and twentythree of the 302, or 8 percent, of the articles published in JAL. Again, percentages increase when only academic librarians are considered. College librarians were responsible for 11 percent (31 of the 276 articles by academic librarians) of the articles in CERL and 10 percent (23 of the 210) of the articles in JAL.

On the surface, chronology seems to have little impact on the number of articles published year by year (see table 1 ). However, when the period is divided into two five-year periods, 1986-1991 and 1991-1996, the difference is significant. The percentage of articles by college librarians compared to those by all academic li- 
brarians was 8 percent for 1986-1991, but 13 percent for 1991-1996 (see table 2).

\section{Authors by Region}

College librarians follow the pattern noted by Buttlar: predominance of authorship from the Northeast and Midwest. ${ }^{21}$ Of the fifty-nine college librarians, twenty-two were from both the Midwest and the Northeast. Other geographical areas wereless well represented: six authors each from the West and Southeast, and three from the Southwest.

Authors by Type of Institution Of the fifty-nine college librarian authors, thirty-three were from BAI institutions, sixteen from BAII, and ten from MAII. Even when authors responsible for multiple articles are counted just once, there is still a preponderance of authors from BAI schools (see table 3 ).

\section{Authors by Gender}

Of the fifty-nine college librarian authors, thirty were female and twenty-nine male. This is consistent with the findings reported by Terry and Hernon, Smith, and Croxen in their studies of academic library authorship in CERL. Terry's 1996 study of publications in CERL details significant change in publications by gender. $^{22}$ From 1939 through the end of the

\begin{tabular}{|lcc|}
\hline \multicolumn{3}{|c|}{ TABLE 3} \\
Authors by Type of \\
\hline \hline Carnstitution \\
Carnie & All & Unique \\
Classifications & Authors & Authors \\
\hline BAI & 33 & 25 \\
BAII & 16 & 10 \\
MAII & 10 & 10 \\
\multicolumn{1}{|c|}{ Total } & 59 & 45 \\
\hline
\end{tabular}

\section{TABLE 2}

Number of Articles Published, 1986-91 and 1991-96, by Institution Type

\begin{tabular}{cccccc}
\hline & \multirow{2}{*}{$\begin{array}{c}\text { Total } \\
\text { Year }\end{array}$} & Articles & \multicolumn{2}{c}{ Authors' Institution } & \multicolumn{2}{c}{\begin{tabular}{c} 
\% College \\
\cline { 3 - 4 }
\end{tabular}} & University & College & Total & Authors \\
\hline 1986 & 75 & 54 & 6 & 60 & $10 \%$ \\
1987 & 62 & 49 & 1 & 50 & 2 \\
1988 & 71 & 52 & 3 & 55 & 5 \\
1989 & 63 & 39 & 4 & 43 & 9 \\
1990 & 66 & 48 & 4 & 52 & 7 \\
1991 & 62 & 42 & 5 & 47 & 10 \\
Total & 399 & 284 & 23 & 307 & 8 \\
& & & & & \\
& Total & Authors' Institution & & $\%$ College \\
\cline { 3 - 4 } Year & Articles & University & College & Total & Authors \\
\hline 1991 & 62 & 42 & 5 & 47 & $10 \%$ \\
1992 & 57 & 34 & 8 & 42 & 19 \\
1993 & 57 & 40 & 6 & 46 & 13 \\
1994 & 61 & 43 & 9 & 52 & 17 \\
1995 & 64 & 43 & 4 & 47 & 9 \\
1996 & 63 & 42 & 4 & 46 & 9 \\
Total & 364 & 244 & 36 & 280 & 13 \\
\hline
\end{tabular}

1970s, the percentage of male to female primary authors was about 80 percent to 20 percent. Beginning in the 1980s, those percentages shifted, reaching the level of 50/50 for the period 1989-1994. Of the 2,072 authors in Buttlar's study, 47.83 percent were male and 52.17 percent female. ${ }^{23}$ Hernon, Smith, and Croxen's findings are similar. Of the 562 authors who had papers accepted by CERL between 1980 and 1991, 47 percent were female and 52 percent male. ${ }^{24}$ General comparisons are difficult because no one collects data on gender of librarians by type of library. The 1997 Statistical Abstract of the U.S. does indicate that 79.8 percent of all librarians, archivists, and curators are female, so although parity in numbers has been achieved, parity in percentages is less certain. ${ }^{25}$

\section{Authors' Collaboration}

Of the fifty-four articles written by college librarian authors, eighteen were coauthored. Data reveal no significant 


\begin{tabular}{|c|c|}
\hline \multicolumn{2}{|l|}{$\begin{array}{c}\text { TABLE } 4 \\
\text { Author Job Titles } \\
\end{array}$} \\
\hline General Category & No. \\
\hline Director (inc. Assistant and Associate) & 15 \\
\hline Reference Librarian & 16 \\
\hline Head of Reference or Public Services & 4 \\
\hline Department Head & 4 \\
\hline Systems Librarian & 3 \\
\hline Technical Services Librarian & 2 \\
\hline Collection Development Librarian & 1 \\
\hline Total & 45 \\
\hline
\end{tabular}

change in collaboration by year, although in some years there is a correlation between collaboration and productivity. For instance, 1994 was the year in which the most college authors collaborated and the most articles by college librarians were published.

Although eleven female and twelve male writers coauthored articles, there were fewer female coauthors in JAL. Males coauthored seven articles in CERL and five in $J A L$, and females coauthored eight articles in CERL and two in JAL.

These findings differ from Terry's, whose study of authorship in CERL indicated a gradual decrease in articles published by single authors and a gradual increase in collaboration by female authors. ${ }^{26}$ From 1939 to 1944, 95.7 percent of published articles were by single authors, a figure that slipped to 85.9 percent for 1965 1969 and to 40.5 percent for 1989-1994. Hernon's finding that 72.2 percent of submissions to $C \mathcal{E} R L$ were by single authors but that more than one-third of the accepted papers had multiple authors makes a significant point- that more single authors submit papers, but that those by multiple authors are published more frequently. ${ }^{27}$

\section{Authors' Positions}

It is not surprising that a preponderance of articles by college librarian authors are on administrative and public service topics. Most college librarian authors are either library directors or reference librarians. This is generally consistent with results reported by Watson, Buttlar, and Hernon. Although Watson's 1977 study was of university librarians only, she singled out administrators as having published disproportionately in relation to their numbers. ${ }^{28}$ Buttlar found that 18.69 percent of publications were by library school faculty, 11.95 percent by academic reference / public services librarians, 9.27 percent by academic library directors, and another 8.18 percent by academic technical services librarians. ${ }^{29}$ In Hernon's study of both submissions to, and publications in CERL from 1980 to 1991, administrators accounted for the largest number of submissions and publications at 28.3 percent, with reference librarians second at 15.8 percent. ${ }^{30}$ These findings hold true for college librarian authors (see table 4).

\section{Authors' Subject Coverage}

Buttlar's comprehensive examination of the subjects covered in library science journals indicated that cataloging and automation were at the top of the list. ${ }^{31}$ Recently, CERL editor Donald E. Riggs noted more submissions on technology. ${ }^{32}$ Yet, only four of the fifty-four articles by college librarians were on technology. This is explained in part by Buttlar, who

\begin{tabular}{|c|c|c|c|c|c|}
\hline \multicolumn{6}{|c|}{$\begin{array}{c}\text { TABLE } 5 \\
\text { Article Subject Coverage } \\
\end{array}$} \\
\hline \multirow[b]{2}{*}{ Subject Area } & \multicolumn{2}{|c|}{ C\&RL } & \multicolumn{2}{|c|}{ JAL } & \multirow[b]{2}{*}{ Tota } \\
\hline & No. & $\%$ & No. & $\%$ & \\
\hline Administration & 18 & 60 & 6 & 26 & 24 \\
\hline Collections & 4 & 13 & 5 & 22 & 9 \\
\hline Interlibrary Loan & 1 & 3 & 2 & 9 & 3 \\
\hline Other & 2 & 6 & 0 & 0 & 2 \\
\hline Public Services & 4 & 13 & 9 & 39 & 13 \\
\hline Technical Services & 2 & 6 & 1 & 4 & 3 \\
\hline Total & 31 & & 23 & & 54 \\
\hline
\end{tabular}




\begin{tabular}{|c|c|c|c|c|}
\hline \multicolumn{5}{|c|}{$\begin{array}{c}\text { TABLE } 6 \\
\text { Most Prolific College Authors } \\
\end{array}$} \\
\hline Author & No. & Carnegie & College* & Position \\
\hline Oberg, Larry R. & 4 & BAI & Albion College & Director of Libraries \\
\hline Mech, Terrence F. & 3 & BAII & King's College & Library Director \\
\hline Hardesty, Larry & 3 & BAI & Eckerd College & $\begin{array}{l}\text { Director of Library } \\
\text { Services }\end{array}$ \\
\hline Bodi, Sonia & 3 & BAII & North Park College & Head Reference Librarian \\
\hline Bechtel, Joan M. & 3 & BAI & Dickinson College & Librarian \\
\hline Kathman, Michael D. & 2 & BAI & College of St. Benedict & Director of Libraries \\
\hline Hovekamp, Tina Maragou & 2 & BAII & $\begin{array}{l}\text { Western State College } \\
\text { of Colorado }\end{array}$ & Reference Librarian \\
\hline Frazer, Stuart L. & 2 & BAII & $\begin{array}{l}\text { West Virginia State } \\
\text { College }\end{array}$ & $\begin{array}{l}\text { Library Instruction \& } \\
\text { Public Service Librarian }\end{array}$ \\
\hline Total & 22 & & & \\
\hline
\end{tabular}

pointed out that reference librarians have been the primary contributors to $C \mathcal{E} R L$, and library directors and administrators the major contributors to JAL..$^{33}$

\section{Authors' Productivity}

A list of the most productive authors follows (see table 6). The eight authors publishing more than one article were divided evenly between BAI and BAII schools, and all were either directors or public services librarians. In other studies, the most prolific authors were male. Although that is also true in this study, there is much greater gender parity among college librarian authors. Budd and Seavey's survey of substantive articles in thirty-six journals from 1983 to 1987 identified thirty-two of the most prolific authors, only eight of whom were women. ${ }^{34}$

\section{Authors' Characteristics}

The fifty-two authors responding to the survey reported their ages, number of years in the profession, degrees held at the time of publication, and previous number of articles published. Like the university librarians in Watson's study, these college librarians had attained a respectable degree of "professional maturity." ${ }^{\prime 35}$ Two-thirds were between the ages of thirty-five and fifty, with five publishing in their early thirties and twelve after age fifty. More than 63 percent had between five and fifteen years of experience. More than 38 percent had published five or more articles at the time they authored in $C E R L$ and/or JAL. Yet, a surprisingly large number of authors, 25 percent, published their first papers in one of these two top journals (see table 7).

\section{Most college librarian authors are either library directors or reference librarians.}

Watson reported that almost 60 percent of the articles in her study were by authors with a subject master's, a Ph.D., or another higher degree. ${ }^{36}$ It is noteworthy that an equally large number of college library authors, 67 percent, had academic degrees above and beyond the master's in library science (see table 8).

\section{Institutional Status and Support}

Twenty-five of the respondents (48\%) indicated that they held faculty status. Virginia Vesper and Gloria Kelley reported that 51 percent of college librarians responded yes to faculty status, defined as 


\begin{tabular}{|c|c|c|c|c|c|}
\hline \multicolumn{6}{|c|}{$\begin{array}{c}\text { TABLE } 7 \\
\text { Characteristics of College Librarians Who } \\
\text { Published Articles in } C \& R L / J A L\end{array}$} \\
\hline \multicolumn{2}{|c|}{ Age } & \multicolumn{2}{|c|}{ Experience } & \multicolumn{2}{|c|}{ Previous Articles } \\
\hline Ages* & No. & Years & No. & $\underline{\text { Number }}$ & No. \\
\hline $25-29$ & 0 & $1-4$ & 3 & None & 13 \\
\hline $30-34$ & 5 & $5-9$ & 18 & One & 8 \\
\hline $35-39$ & 9 & $10-14$ & 15 & Two & 4 \\
\hline $40-44$ & 11 & $15-19$ & 6 & Three & 5 \\
\hline $45-49$ & 14 & $20-24$ & 6 & Four & 2 \\
\hline $50-54$ & 8 & $25-29$ & 3 & Five & 3 \\
\hline $55-59$ & 3 & $30-34$ & 0 & Six & 5 \\
\hline $60-64$ & 1 & $35-39$ & 1 & Seven and up & 12 \\
\hline
\end{tabular}

"the acceptance of the same responsibilities and privileges as teaching faculty." ${ }^{37}$ However, when compared to studies of other library authors, the 48 percent is remarkably low; Floyd and Phillips reported that 74 percent of the academic library authors they studied had faculty status. $^{38}$

One of the major obstacles to publication by librarians is the absence of release time for research and writing. This appears to be an acute problem in college libraries where staffs are smaller and work schedules are often less flexible. Sixty-seven percent of respondents did not have release time to prepare articles. Some indicated that they were on unpaid leave or between jobs at the time they wrote their papers; others prepared their articles during regular working hours as reflected in the following comments: "I did not get formal time off to do it, but

\begin{tabular}{|c|c|}
\hline \multicolumn{2}{|l|}{$\begin{array}{l}\text { Table } 8 \\
\text { Graduate Degrees When } \\
\text { Articles Were Published }\end{array}$} \\
\hline Degree & No. \\
\hline MLS Only & 17 \\
\hline MLS and One Master's Degree & 23 \\
\hline $\begin{array}{l}\text { MLS, Master's Degree, and } \\
\text { Doctoral Degree }\end{array}$ & 12 \\
\hline
\end{tabular}

then I guess I released myself from doing other things to do it."

Financial support for scholarship by college librarians was even rarer than release time. Only four authors received funding from external sources and only six from within their own institutions. However, several authors received other forms of assistance from their colleges, such as secretarial support, access to computers and databases, and free photocopying, printing, and postage.

Mitchell and Swieszkowski's study of university libraries provides a sharp contrast to these findings. Professional staff were eligible for sabbaticals in more than 76 percent of these libraries, 50 percent of librarians were eligible for release time, and more than 89 percent of academic institutions made funding available to library authors (see table 9). ${ }^{39}$

\section{Factors Motivating Authors to Write}

Although previous studies affirmed the tenure requirement as the key impetus to publishing, this is clearly not true for college librarians. ${ }^{40}$ Indeed, more than 50 percent of the authors considered tenure the least important motivating factor. The term promotion was subject to more individual interpretation: One respondent ranked it important in the sense of "impressing one's supervisor," but not so in 


\begin{tabular}{|lcr|}
\hline \multicolumn{3}{|c|}{ TABLE 9 } \\
Institutional Status and Support for \\
College Librarian Authors \\
\hline \hline & Yes & No \\
\hline Faculty Status & 25 & 27 \\
Release Time & 17 & 35 \\
Direct Financial Support & 10 & 42 \\
\hline
\end{tabular}

terms of "achieving a higher rank." Few college librarians ranked promotion as very important, and one-third rated it least important. Floyd and Phillips reported peer pressure from colleagues as a significant factor in motivating librarians to publish, yet this was of little importance to college librarian authors. ${ }^{41}$ The same is true for academic achievement: Only eight of the articles were written in conjunction with a course or a dissertation.

The vast majority of college librarians published to share their innovations and/ or concerns and to achieve recognition: More than 70 percent considered "sharing innovations and concerns" as the first or second reason for writing, and more than 70 percent, "recognition." Several respondents added other factors they considered of utmost importance: "To be honest, I was simply curious-and I like to write to satisfy my curiosity"; "sheer enjoyment"; "personal satisfaction"; "commitment to the profession." These com- ments confirm Haas, Milton, and Quinn's observation that "the motivation to publish cannot be capsulized by the 'publish or perish' phrase because not every librarian is bound by such requirements" (see table 10). ${ }^{42}$

\section{Conclusion}

Previous studies of academic library authorship analyzed the literature from several perspectives. In contrast, this paper focused exclusively on college librarians and the articles they contributed to two specific journals. When the results from past studies are compared with the results from this one, interesting similarities and differences between college librarian authors and their university counterparts emerge.

Most authors from academic libraries came from the Midwest and the Northeast. Both males and females published roughly the same number of articles, despite the fact that there were more women than men in the field. A small percentage of librarians, administrators, contributed proportionally more than might be expected given their numbers.

How did college and university librarian authors differ? First, college librarians published less and collaborated less. Second, in terms of these two journals, they wrote less about technology, systems-related issues, and cataloging, and more

\section{TABLE 10}

Reasons College Librarians Published Articles in $C \& R L$ and $J A L$ Ranked by Level of Importance (One = most; Six = least)

\begin{tabular}{|c|c|c|c|c|c|c|c|}
\hline & $\begin{array}{c}\text { One } \\
\text { No. }(\%)\end{array}$ & $\begin{array}{c}\text { Two } \\
\text { No. }(\%)\end{array}$ & $\begin{array}{c}\text { Three } \\
\text { No. (\%) }\end{array}$ & $\begin{array}{c}\text { Four } \\
\text { No. (\%) }\end{array}$ & $\begin{array}{c}\text { Five } \\
\text { No. }(\%)\end{array}$ & $\begin{array}{c}\text { Six } \\
\text { No. }(\%) \\
\end{array}$ & Total \\
\hline Tenure & $5 \quad(9.6)$ & $5 \quad(9.6)$ & $8(15.4)$ & $4 \quad(7.7)$ & $3 \quad(5.8)$ & 27 (51.9) & 52 \\
\hline Promotion & $5 \quad(9.6)$ & $3 \quad(5.8)$ & $15(28.8)$ & $11(21.2)$ & $3 \quad(5.8)$ & $15(28.8)$ & 52 \\
\hline Recognition & $13(25.0)$ & $25(48.1)$ & $8(15.4)$ & 1 (1.9) & $\begin{array}{ll}0 & (0.0)\end{array}$ & $5 \quad(9.6)$ & 52 \\
\hline Peer Pressure & 1 (1.9) & 1 (1.9) & $3 \quad(5.8)$ & $6(11.5)$ & $12(23.1)$ & $29(55.8)$ & 52 \\
\hline $\begin{array}{l}\text { Academic } \\
\text { Achievement }\end{array}$ & $8(15.4)$ & $\begin{array}{ll}0 & (0.0)\end{array}$ & $\begin{array}{ll}0 & (0.0)\end{array}$ & $6(11.5)$ & $2(3.8)$ & $36(69.2)$ & 52 \\
\hline $\begin{array}{l}\text { Share Innova- } \\
\text { tions/Concern }\end{array}$ & $\begin{array}{l}25(48.1) \\
n s\end{array}$ & $12(23.1)$ & $8(15.4)$ & 1 (1.9) & $3 \quad(5.8)$ & $3 \quad(5.8)$ & 52 \\
\hline
\end{tabular}


about areas of management and administration. Third, women were well represented among the most prolific college librarian authors.

The most compelling differences, however, were the factors motivating authors to write. Clearly, college librarians did not publish to achieve tenure or promotion. Pressure from colleagues was not a major influence. Although they received less

\section{Clearly, college librarians did not publish to achieve tenure or promotion.}

in the way of release time or financial support, they found the time, energy, and wherewithal to create articles significant enough to be accepted by the top two journals of academic librarianship.

How did they manage to succeed? A composite profile of the college librarians who published in CERL and/or JAL between 1986 and 1996 offers some clues. Successful authors were experienced professionals between thirty-five and fifty years of age. They were library directors or reference librarians, most likely at prestigious BAI institutions in the Midwest or the Northeast. They were talented and disciplined enough to have achieved a subject master's or doctorate degree in addition to the master's in library science. With or without the veneer of tenure, they were motivated researchers and writers who found the time to pursue scholarly activities at both work and home. They enjoyed the opportunity to share their research with colleagues and were rewarded by the recognition they received as authors on their campuses and in the profession.

Although acceptance of a paper in $C \mathcal{E} R L$ and/or JAL often came at the pinnacle or end of a college librarian's career, college librarians contributed to other journals, as well as to books, reports, and conference papers. The data reported in this study will accrue greater meaning when additional types of publication by college librarians are analyzed. This study was initiated in part to begin and to encourage such research.

\section{Notes}

1. "Ready, Set, Go: Publish and Present" was sponsored during the 1998 midwinter conference; "Topics, Tips and Techniques for College Librarians Submitting Papers and Panel Presentations in Nashville and Beyond," during the 1996 midwinter conference.

2. Lynn W. Livingston, ed. InPrint: Publishing Opportunities for College Librarians (Chicago: ALA, 1997).

3. Sylvia C. Krausse and Janice F. Sieburth, "Patterns of Authorship in Library Journals by Academic Librarians," Serials Librarian 9 (spring 1985): 132-33.

4. John M. Budd and Charles A. Seavey, "Characteristics of Journal Authorship by Academic Librarians," College E Research Libraries 51 (Sept. 1990): 466.

5. Peter Hernon, Allen Smith, and Mary Bailey Croxen, "Publication in College E Research Libraries: Accepted, Rejected, and Published Papers, 1980-1991," College E Research Libraries 54 (July 1993): 311.

6. Lois Buttlar, "Analyzing the Library Periodical Literature: Content and Authorship," College E Research Libraries 52 (Jan. 1991): 38.

7. James L. Terry, "Authorship in College E Research Libraries Revisited: Gender, Institutional Affiliation, Collaboration," College \& Research Libraries 57 (July 1996): 379-81.

8. W. Bede Mitchell and L. Stanislava Swieszkowski, "Publication Requirements and Tenure Approval Rates: An Issue for Academic Librarians," College E Research Libraries 46 (May 1985): 253.

9. Barbara L. Floyd and John C. Phillips, “A Question of Quality: How Authors and Editors Perceive Library Literature," College E Research Libraries 58 (Jan. 1997): 85.

10. Betsy Park and Robert Riggs, "Tenure and Promotion: A Study of Practices by Institutional Type," Journal of Academic Librarianship 19 (May 1993): 75-77.

11. Floyd and Phillips, "A Question of Quality," 85. 
12. Paula D. Watson, "Production of Scholarly Articles by Academic Librarians and Library School Faculty," College \& Research Libraries 46 (July 1985): 334.

13. Kathleen Kenny, Linda D. Tietjen, and Rutherford W. Witthus, "Increasing Scholarly Productivity among Library Faculty: Strategies for a Medium-Sized Library," Journal of Academic Librarianship 16 ( Nov. 1990): 277-79.

14. Park and Riggs, "Tenure and Promotion," 72-77; Charles B. Lowry, "The Status of Faculty Status for Academic Librarians: A Twenty-Year Perspective," College \& Research Libraries 54 (Mar. 1993): 163-72.

15. "Carnegie Foundation's Classification of 3,600 Institutions of Higher Education," Chronicle of Higher Education (Apr. 6, 1994): A18.

16. Mary K. Sellen, "Bibliometrics in Information Science: A Citation Analysis of Two Academic Library Journals," College \& Research Libraries 45 (Mar. 1984): 129.

17. Watson's study of authors' affiliations in eleven library science periodicals from 1979 to 1983 concluded that "academic librarian authors are the primary contributors to College $\mathcal{E}$ Research Libraries and to the Journal of Academic Librarianship" (p.337). Krausse found that the percent of articles by authors from academic libraries was highest for these two periodicals (p. 129).

18. Paula de Simone Watson, "Publication Activity among Academic Librarians," College $\mathcal{E}$ Research Libraries 38 (Sept. 1977): 375-77.

19. Search of 1994 Integrated Postsecondary Education Data System files by Department of Education staff, Mar. 1998.

20. "ACRL Membership Statistics," College \& Research Libraries News 58 (Dec. 1997): 783.

21. Buttlar, "Analyzing the Library Periodical Literature," 38.

22. Terry, "Authorship in College \& Research Libraries Revisited," 379.

23. Buttlar, "Analyzing the Library Periodical Literature," 41.

24. Hernon, Smith, and Croxen, "Publication in College E Research Libraries," 311.

25. U.S. Bureau of the Census, Statistical Abstract of the United States 1997 (Washington D.C.: U.S. Government Printing Office, 1997), Table 645.

26. Terry, "Authorship in College \& Research Libraries Revisited," 381.

27. Hernon, Smith, and Croxen, "Publication in College $\mathcal{E}$ Research Libraries," 311.

28. Watson, "Publication Activity among Academic Librarians," 379.

29. Buttlar, "Analyzing the Library Periodical Literature," 43.

30. Hernon, Smith, and Croxen, "Publication in College E Research Libraries," 309.

31. Buttlar, "Analyzing the Library Periodical Literature," 48. 97.

32. Donald E. Riggs, "Editor's Observations," College \& Research Libraries 58 (Nov. 1997): 496-

33. Buttlar, "Analyzing the Library Periodical Literature," 43-44.

34. Budd and Seavey, "Characteristics of Journal Authorship by Academic Librarians," 465.

35. Watson, "Publication Activity among Academic Librarians," 377.

36. Ibid., 379.

37. Virginia Vesper and Gloria Kelley, comp., Criteria for Promotion and Tenure for Academic Librarians: Clip Note \#26 (Chicago: ALA, 1997), 2.

38. Floyd and Phillips, "A Question of Quality," 85.

39. Mitchell and Swieszkowski, "Publication Requirements and Tenure Approval Rates," 253.

40. Ibid., 249-55; Floyd and Phillips, "A Question of Quality," 81-93.

41. Floyd and Phillips, "A Question of Quality," 85.

42. Leslie Haas, Suzanne Milton, and Aimee Quinn, "Surviving the Publishing Process: A Beginner's Guide," RQ 36 (winter 1996): 230. 